\section{Photosynthetic Irradiance and Nutrition Effects on Growth of English Ivy in Subirrigation Systems}

\author{
Svoboda V. Pennisi ${ }^{1}$ \\ Department of Horticulture, 1109 Experiment Street, College of Agricultural \\ and Environmental Sciences, University of Georgia Agricultural Experiment \\ Station, Griffin, GA 30223
}

\author{
Marc W. van Iersel \\ Department of Horticulture, The University of Georgia, 1111 Plant Sciences \\ Building, The University of Georgia, Athens, GA 30602-7273
}

\author{
Stephanie E. Burnett \\ Department of Plant, Soil, and Environmental Sciences, University of Maine, \\ 5722 Deering Hall, Orono, ME 04469
}

Additional index words. foliage plants, foliage variegation, ebb-and-flow systems

\begin{abstract}
The growth of three english ivy cultivars in ebb-and-flow subirrigation systems was examined under three photosynthetic photon flux $(P P F)$ treatments (low, medium, or high, corresponding to an average daily $P P F$ of $3.2,5.4$, or $8.5 \mathrm{~mol} \cdot \mathrm{m}^{-2} \cdot \mathrm{d}^{-1}$, respectively) and four fertilizer concentrations $\left(0,100,200\right.$, or $\left.300 \mathrm{mg} \cdot \mathrm{L}^{-1} \mathrm{~N}\right)$ geared toward production of acclimatized foliage plants. Marketable quality english ivy can be subirrigated with $100 \mathrm{mg} \cdot \mathrm{L}^{-1} \mathrm{~N}$. Although $8.5 \mathrm{~mol} \cdot \mathrm{m}^{-2} \cdot \mathrm{d}^{-1}$ produced the maximum shoot dry weight (SDW), good quality plants also were produced under $5.4 \mathrm{~mol} \cdot \mathrm{m}^{-2} \cdot \mathrm{d}^{-1}$. 'Gold Child', 'Gold Dust', and 'Gold Heart' english ivy produced with low fertility and low light may be better acclimatized and show superior performance in interior environments. Under light levels lower than $8.5 \mathrm{~mol} \cdot \mathrm{m}^{-2} \cdot \mathrm{d}^{-1}$, 'Gold Heart' had less variegation $(12 \%$ or $21 \%$ for ivy grown under 3.2 or $5.4 \mathrm{~mol} \cdot \mathrm{m}^{-2} \cdot \mathrm{d}^{-1}$, respectively). 'Gold Dust' and 'Gold Child' had $65 \%$ and $22 \%$ variegated leaf area, respectively, when grown under $5.4 \mathrm{~mol} \cdot \mathrm{m}^{-2} \cdot \mathrm{d}^{-1} P P F$. Under 5.4 $\mathrm{mol} \cdot \mathrm{m}^{-2} \cdot \mathrm{d}^{-1} P P F$, 'Gold Dust' retains attractive foliage with overall perception of increased lighter-green coloration.
\end{abstract}

Foliage plant production represents an important agricultural industry in the United States with a net wholesale value of $\$ 574$ million in 2000 (U.S. Dept. of Agriculture, 2001). The genus Hedera (L.) species and cultivars are some of the most popular plants for hanging baskets, representing an important component of the foliage plant product mix and ranking third with $6.5 \%$ of total sales in Florida (McConnell et al., 1989). English ivy (Hedera helix $\mathrm{L}$.) is the predominant species in the trade, having $>400$ cultivars, a third of which are commercially available (Pennisi et al., 2001). The juvenile form, typical of most cultivars in the trade, is evergreen with palmately-lobed leaves on flexible aerial root-bearing stems. Depending on the cultivar, ivies are used as indoor plants in hanging baskets, pots, topiaries, dish gardens, in interiorscapes as ground, wall or tree trunk covers. In the landscape, ivies are used as a specimen plant, espalier, hedge, tall screen, mass planting, ground, wall, and tree trunk cover. The florist industry also uses ivies as cut vines in flower arrangements. Training ivies into various geometrical shapes,

Received for publication 3 May 2005. Accepted for publication 18 June 2005. We thank Orville Lindstrom and Carol Robacker for review of the manuscript and constructive criticism.

${ }^{1}$ To whom reprint requests should be addressed; e-mail bpennisi@uga.edu. guidelines for production of high-quality foliage plants with environmentally-sound cultural practices.

\section{Materials and Methods}

Plant material. Rooted liners of english ivy 'Gold Child', 'Gold Dust', and 'Gold Heart' were obtained from a commercial grower (Riverbend Nursery, Va.). All three cultivars are variegated; 'Gold Child' has yellow margins and a green center, 'Gold Dust' has a yellow-and-green speckled leaf, and 'Gold Heart' has yellow center and green margins. For uniformity, all ivy vines were trimmed to a 5 -cm length at the initiation of the experiment. Liners were transplanted into $10-\mathrm{cm}(510-\mathrm{mL})$ pots filled with soilless growing medium (MetroMix 500; The Scotts Co., Marysville, Ohio) containing peatmoss, composted pine bark, vermiculite, and a starter fertilizer. The initial electrical conductivity (EC) of the substrate was $2.0 \mathrm{dS} \cdot \mathrm{m}^{-1}$, using the Virginia Tech extraction method [VTEM or pour-thru method (Yeager et al., 1997)] The pots were placed on 1.2 $\times 2.4-\mathrm{m}^{2}$ ebb-and-flow benches (Midwest GroMaster, St. Charles, Ill.) and subirrigated with 20N-4.4P-16.6K fertilizer solutions (Peter's 20-10-20 Peat-Lite special, The Scotts Co., Marysville, Ohio). Fertilizer solutions were stored in plastic barrels $(210 \mathrm{~L})$ and pumped into the watertight trays of the ebb-and-flow system daily using submersible pumps (NoKorode\#2; Little Giant, Oklahoma City, Okla). The bottom of the pots were immersed in the fertilizer solution for about $13 \mathrm{~min}(5 \mathrm{~min}$ for pumping and $8 \mathrm{~min}$ for draining). The fertilizer $\mathrm{EC}$ in the barrels was measured using an EC meter (model M90; Corning, Corning, N.Y.) and adjusted weekly when the barrels were refilled. Plants were grown in a greenhouse covered with double-layered polyethylene. The temperature control was set at $21 / 18^{\circ} \mathrm{C}$ for day/night, respectively (Wadsworth Systems, Arvada, Colo.). Quantum sensors (QSO-SUN, Apogee Instruments Inc., Logan, Utah) connected to a datalogger (CR10X; Campbell Sci., Logan, Utah) were arranged in the center of each experimental unit to measure $P P F$ as a percentage of incident $P P F$ in each treatment. Incident $P P F$ above the experimental units was measured throughout the experiment with a quantum sensor (LI-190SA; LI-COR, Lincoln, Nebr.).

Treatments. Plants were subirrigated with one of four fertilizer concentrations $(0,100$, $200,300 \mathrm{mg} \cdot \mathrm{L}^{-1} \mathrm{~N}$, respectively) and grown under one of the three $P P F$ treatments (high, medium, low, corresponding to an average daily $P P F$ of $8.5,5.4$, and $3.2 \mathrm{~mol} \cdot \mathrm{m}^{-2} \cdot \mathrm{d}^{-1}$, respectively). Each ebb-and-flow bench was divided into three zones using shade cloth of varying density $(0,37 \%$ or $62 \%$ shade $)$ to provide different $P P F$ levels.

Measurements. Ten weeks after transplanting, the experiment was terminated. Data on leaf area, shoot dry weight, vine length, internode length, chlorophyll content, and $\mathrm{pH}$ and electrical conductivity (EC) of the growing medium were collected. EC and $\mathrm{pH}$ of the growing medium for two plants in each experi- 
mental unit were measured using the pour-thru method.At termination, tissue samples of 'Gold Child' were tested for a complete foliar nutrient analysis. Leaf chlorophyll content of two randomly selected leaves in each experimental unit was measured using a chlorophyll meter (SPAD-502; Minolta Co., Tokyo, Japan). SPAD measurements were taken to maximize the measurement of non-variegated leaf areas. They were taken in the green leaf margin of the lamina for 'Gold Heart', in the center of the green lamina for 'Gold Child', and in the center of the lamina for 'Gold Dust'.

Leafarea from 12 representative leaves that emerged under treatment conditions was measured using an area meter (LI-3100, LI-COR). Leaves from two plants in each experimental unit were photographed and sampled for variegation analysis in Adobe Photoshop software (Adobe Systems, Inc., San Jose, Calif.). The entire leaf area was measured digitally in
Photoshop, then the green area was measured. Percent variegation was calculated as: [ (whole leafarea-green area $) /($ whole leafarea $)] \times 100$. Leaves were dried then in a forced-air oven maintained at $80^{\circ} \mathrm{C}$ for 1 week, then specific leaf area (SLA) was calculated as the ratio of leaf area to leaf dry weight. Shoots (leaves and stems) from two plants in each experimental unit were dried as described above and the dry weight was measured.

Experimental design. Treatments were organized in a split-split-plot design; each fertilizer concentration was a whole plot, the $P P F$ levels were the main split, and the cultivars were the sub split plots. The $P P F$ levels $\left(3.2,5.4\right.$, or $\left.8.5 \mathrm{~mol} \cdot \mathrm{m}^{-2} \cdot \mathrm{d}^{-1}\right)$ and the fertilizer levels $\left[0,100,200\right.$, or $300 \mathrm{mg} \cdot \mathrm{L}^{-1} \mathrm{~N}$ $(20 \mathrm{~N}-4.4 \mathrm{P}-16.6 \mathrm{~K})]$ were chosen from recommendations for production of acclimatized foliage plants (Conover and Poole, 1981). A group of four plants under each $P P F$ level consisted an experimental unit. Subsamples were averaged, and data were analyzed for all cultivars together using general linear models in Statistical Analysis Software (SAS institute, Cary, N.C.) to test for two-way and three-way interactions and significant correlations $(P \leq$ 0.05 were considered statistically significant). Means separation analysis [Fisher's protected least significant difference (LSD)] was used to further analyze the data $(P=0.05)$.

\section{Results and Discussion}

PPF effects. The effect of PPF on growth was similar for all three ivy cultivars and at all fertilizer concentrations (i.e. no significant interactions involving $P P F)$. All cultivars were larger when they were grown with more light up to $8.5 \mathrm{~mol} \cdot \mathrm{m}^{-2} \cdot \mathrm{d}^{-1}$ (Fig. 1A-D). Vine length of all three cultivars increased with increasing $P P F$, partly due to a significant increase in
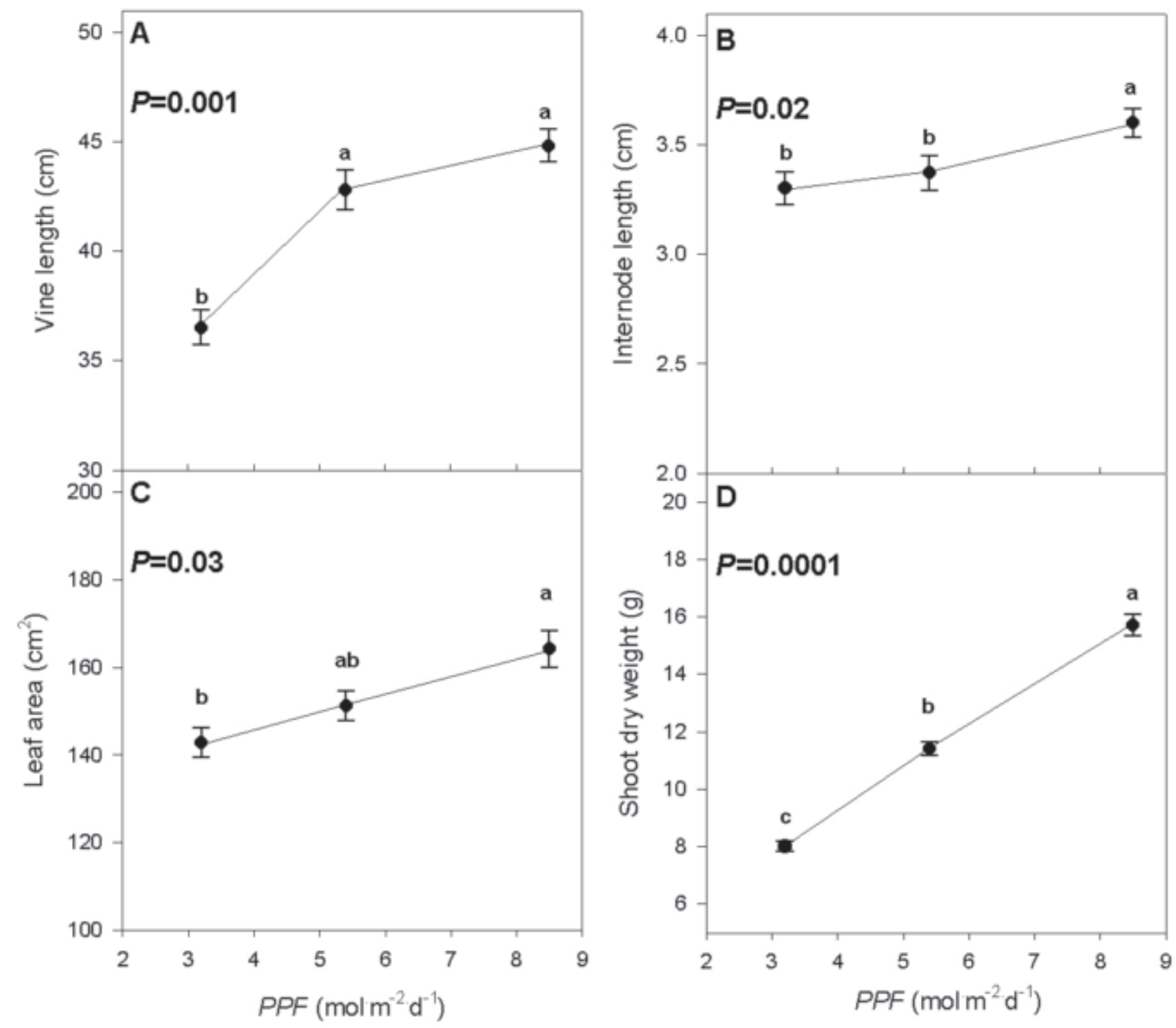

Fig. 1. Effects of $P P F$ on vine length (A), internode length (B), leaf area (C), and shoot dry weight (D) of three english ivy (Hedera helix L.) cultivars: 'Gold Child', 'Gold Dust', and 'Gold Heart'. The means for all three cultivars are shown with standard error bars, with the LSD mean separations represented by letters above the standard error bars. 
Table 1. Differences in growth parameters and leaf chlorophyll concentration among three ivy cultivars. Means within a column followed by the same letter are not significantly different (Fisher's protected LSD, $P=0.05$ ). Growth parameters that were not different among cultivars (growing medium electrical conductivity, vine length, and percent variegated leaf area) are not shown. There were no significant interactions between cultivar and/or $P P F$ and/or fertilizer concentration, so means for each cultivar were averaged over all $P P F$ levels and fertilizer concentrations.

\begin{tabular}{|c|c|c|c|c|c|}
\hline Cultivar & $\begin{array}{l}\text { Internode } \\
\text { length } \\
(\mathrm{cm})\end{array}$ & $\begin{array}{l}\text { Leaf } \\
\text { area } \\
\left(\mathrm{cm}^{2}\right)\end{array}$ & $\begin{array}{c}\text { SLA } \\
\left(\mathrm{cm}^{2} \cdot \mathrm{g}^{-1}\right)\end{array}$ & $\begin{array}{l}\text { Shoot } \\
\text { dry wt } \\
\text { (g) }\end{array}$ & $\begin{array}{l}\text { Chlorophyll } \\
\text { (SPAD) }\end{array}$ \\
\hline H. helix 'Gold Child' & $3.3 \mathrm{~A}$ & $181 \mathrm{~A}$ & $200 \mathrm{~A}$ & $10.4 \mathrm{~B}$ & $25 \mathrm{~B}$ \\
\hline H. helix 'Gold Dust' & $3.1 \mathrm{~B}$ & $164 \mathrm{~B}$ & $197 \mathrm{~A}$ & $12.9 \mathrm{~A}$ & $23 \mathrm{~B}$ \\
\hline H. helix 'Gold Heart' & $3.9 \mathrm{C}$ & $114 \mathrm{C}$ & $182 \mathrm{~B}$ & $11.8 \mathrm{~A}$ & $39 \mathrm{~A}$ \\
\hline$P$ & 0.0001 & 0.0001 & 0.0001 & 0.002 & 0.0001 \\
\hline
\end{tabular}

internode length (Fig. 1A and B). The maximum vine and internode lengths were 45 and $3.6 \mathrm{~cm}$, respectively, for ivy grown under 8.5 $\mathrm{mol} \cdot \mathrm{m}^{-2} \cdot \mathrm{d}^{-1} P P F$ (Fig. 1Aand B). However, the greatest difference in internode lengths among $P P F$ treatments was about $1 \mathrm{~cm}$. This small difference in internode length, while statistically significant, is unlikely to be important to commercial ivy growers. Low irradiance can cause excessive internode elongation in ivy, resulting in unattractive plants (Pennisi et al., 2001). In the current study, however, even the lowest light level yielded marketable quality plant material. The cultivars had significantly different internode lengths; 'Gold Heart' had the longest internode length, followed by 'Gold Child' and 'Gold Dust' (Table 1).

Both leaf area and shoot dry weight increased with increasing light level (Fig. $1 \mathrm{C}$ and D). 'Gold Dust' had significantly greater leaf area than 'Gold Heart', while 'Gold Child' had the largest leaf area, but the lowest shoot dry weight of all three cultivars (Table 1). Other foliage plants, such as peperomia Peperomia obtusifolia (L.) 'Albomarginata' also have greater shoot dry weights when grown at higher light levels (Shen and Seely, 1983). Some obligate shade plants, such as Dracaena sanderana (Hort. Mast.) increase shoot dry weight and leafarea when grown with more shade up to $63 \%$ shade (Vladimirova et al., 1997). Hedera helix canariensis (Willd.) had the greatest leaf area when grown at 210 $\mu \mathrm{mol} \cdot \mathrm{m}^{-2} \cdot \mathrm{s}^{-1} P P F$ (Al-Juboory et al., 1998). In our experiment, ivy was grown under low light conditions in order to be acclimatized to interior conditions (Conover and Poole, 1981). Yeh and Hsu (2004) found that H. helix (L.) 'Ingelise' and 'Mini Adam' (two variegated english ivy cultivars) increased shoot dry weight when grown at light levels up to $2.9 \mathrm{MJ} \cdot \mathrm{m}^{-2} \cdot \mathrm{d}^{-1}$ of light (optimal shading about 60\%). Three of the four english ivy cultivars examined in their experiment decreased shoot or internode lengths and leaf area when they were grown at $7.2 \mathrm{MJ} \cdot \mathrm{m}^{-2} \cdot \mathrm{d}^{-1}$ compared to $1.7 \mathrm{MJ} \cdot \mathrm{m}^{-2} \cdot \mathrm{d}^{-1}$ of light (Yeh and Hsu, 2004).

All ivy cultivars grown in our experiment had greater shoot dry weights, vine lengths, internode lengths, and leafareas when grown with the greatest amount of light $\left(8.5 \mathrm{~mol} \cdot \mathrm{m}^{-2} \cdot \mathrm{d}^{-1}\right.$ $P P F ; 62 \%$ shade). Interior environments are commonly characterized by light levels considerably lower than $8.5 \mathrm{~mol} \cdot \mathrm{m}^{-2} \cdot \mathrm{d}^{-1} P P F$. It would be expected that acclimated english ivy that was grown under low irradiance for the entire production cycle would exhibit superior performance in interiorscapes (Blessington and
Collins, 1993). In the current study, english ivy were smaller under $5.4 \mathrm{~mol} \cdot \mathrm{m}^{-2} \cdot \mathrm{d}^{-1}$, but plants were still high quality. Consequently, growers could acclimate plants at this lower light level while maintaining high quality.

Variegation may increase or decrease under high light and the response tends to be species specific (Bequette et al., 1985; Carpenter and Nautiyal, 1969; Conover and Poole, 1981; Vladimirova et al., 1997). For example, $A s$ pidistra elatior 'Variegata' (B1.), Codiaeum variegatum 'Yellow Jade' (Blume), Epipremnum aureum (Bunt. E. pinnatum), Lonicera japonica var. aureo-reticulata (Thunb.), and Tradescantia sp.were more variegated under high than low light intensity (Hong et al., 1994; HyeRan et al., 1998; Nam and Kwack, 1992; Stamps, 1995; YuKyeong et al., 1997). But Dracaena sanderana 'Ribbon' and Peperomia obtusifolia 'Albomarginata', both shade obligate species, were more variegated when grown under low light (Shen and Seeley, 1983; Vladimirova et al., 1997).

In this experiment, there was a significant interaction between cultivar and light for the variegated leaf area measurements (Fig. 2). 'Gold Child' and 'Gold Heart' exhibited less

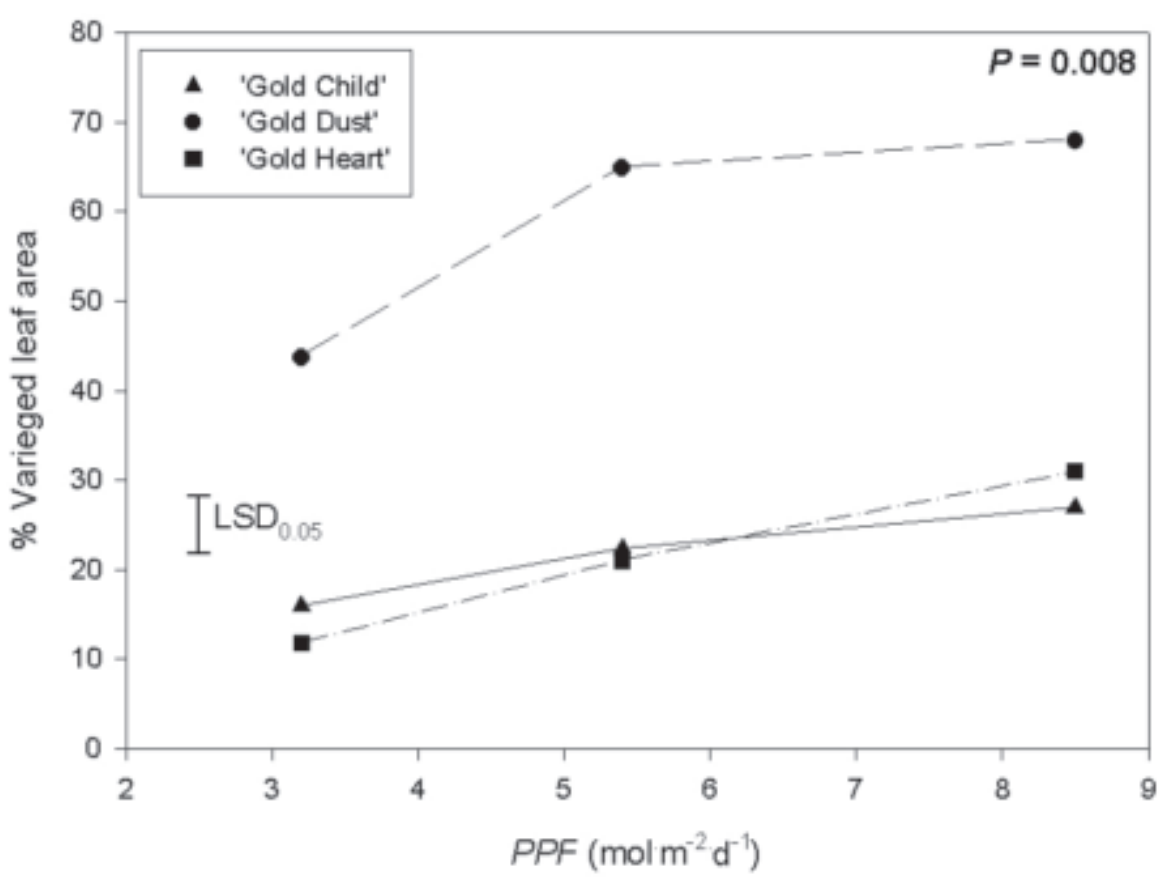

Fig. 2. Effects of $P P F$ on the variegated leaf area of three english ivy (Hedera helix L.) cultivars: 'Gold Child', 'Gold Dust', and 'Gold Heart'. There was a significant interaction between $P P F$ and cultivar $(P=0.008)$. The mean for each $P P F$ and cultivar combination is shown (averaged over four fertilizer concentrations). variegated when grown under $3.2 \mathrm{~mol} \cdot \mathrm{m}^{-2} \cdot \mathrm{d}^{-1}$ variegation than 'Gold Dust' (Figs. 2 and 3A and $\mathrm{C}$ ). 'Gold Heart' has the least variegation when grown under $3.2 \mathrm{~mol} \cdot \mathrm{m}^{-2} \cdot \mathrm{d}^{-1} P P F$ and the most variegation when grown under $8.5 \mathrm{~mol} \cdot \mathrm{m}^{-2} \cdot \mathrm{d}^{-1} P P F$ (Figs. 2 and $3 \mathrm{C} ; 3.2$ $\mathrm{mol} \cdot \mathrm{m}^{-2} \cdot \mathrm{d}^{-1} P P F: 12 \% ; 8.5 \mathrm{~mol} \cdot \mathrm{m}^{-2} \cdot \mathrm{d}^{-1} P P F$ : $31 \%$ ). Variegated cultivars of english ivy are considered less attractive when they express less foliar variegation. 'Gold Heart' english ivy, for example, nearly lost its characteristic variegation in the center of the leaf when grown under $3.2 \mathrm{~mol} \cdot \mathrm{m}^{-2} \cdot \mathrm{d}^{-1} P P F$ (Fig. $3 \mathrm{C}$ ). 'Gold Heart' had significantly more variegation when grown under more light (Fig. 2). However, the difference between the two lowest variegation levels was quite small (about $10 \%$ ) and barely larger than the LSD value. 'Gold Heart' would have the most variegation and be considered most attractive when grown under $8.5 \mathrm{~mol} \cdot \mathrm{m}^{-2} \cdot \mathrm{d}^{-1} P P F$. However, 'Gold Heart' english ivy grown under $5.4 \mathrm{~mol} \cdot \mathrm{m}^{-2} \cdot \mathrm{d}^{-1}$ $P P F$ had acceptable amounts of variegation. 'Gold Child' and 'Gold Dust', also were least $P P F(16 \%$ and $44 \%$ for 'Gold Child' and 'Gold Dust', respectively; Figs. 2 and $3 \mathrm{~A}$ and B). However, they did not have significantly more variegation when grown under $8.5 \mathrm{~mol} \cdot \mathrm{m}^{-2} \cdot \mathrm{d}^{-1}$ $P P F$ compared to $5.4 \mathrm{~mol} \cdot \mathrm{m}^{-2} \cdot \mathrm{d}^{-1} P P F$ (Figs. 2 and $3 \mathrm{~A}$ and $\mathrm{B}$ ). There appears to be no need to grow 'Gold Dust' or 'Gold Child' under more than $5.4 \mathrm{~mol} \cdot \mathrm{m}^{-2} \cdot \mathrm{d}^{-1} P P F$ for adequate variegation.

Fertilizer. There was a three-way interaction (fertilizer concentration $\times P P F \times$ cultivar) for EC of the growing medium $(P=0.002)$. Within each cultivar and light level combination, EC increased with increasing fertilizer concentration (Table 2). Within every cultivar and light combination, EC was between 0.20 

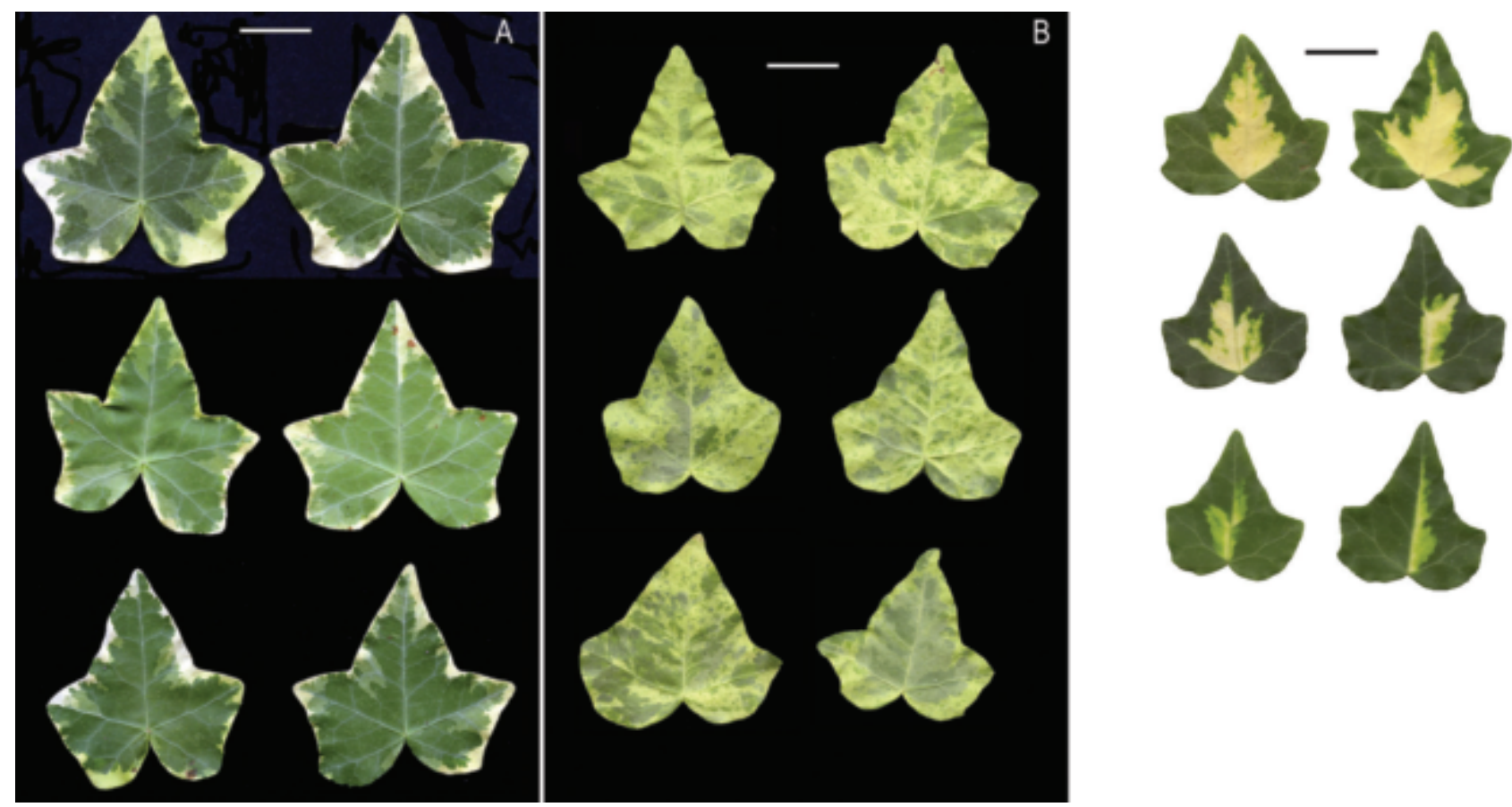

Fig. 3. Leaf variegation of three cultivars of english ivy (Hedera helix L.) grown under PPF levels and fertilized with $100 \mathrm{mg} \cdot \mathrm{L}^{-1} \mathrm{~N}$; (A) H. helix 'Gold Child', (B) H. helix 'Gold Dust', and (C) H. helix 'Gold Heart'; (top) $8.5 \mathrm{~mol} \cdot \mathrm{m}^{-2} \cdot \mathrm{d}^{-1}$, (middle) $5.4 \mathrm{~mol} \cdot \mathrm{m}^{-2} \cdot \mathrm{d}^{-1}$, (bottom) $3.2 \mathrm{~mol} \cdot \mathrm{m}^{-2} \cdot \mathrm{d}^{-1}$. Bar $=20 \mathrm{~mm}$.

and $0.26 \mathrm{dS} \cdot \mathrm{m}^{-1}$ when ivy were fertilized with $0 \mathrm{mg} \cdot \mathrm{L}^{-1} \mathrm{~N}$ and between 2.67 and $3.37 \mathrm{dS} \cdot \mathrm{m}^{-1}$ when ivy were fertilized with $300 \mathrm{mg} \cdot \mathrm{L}^{-1} \mathrm{~N}$.

There was a two-way interaction (fertilizer concentration $\times P P F)$ for $\mathrm{pH}$ of the growing medium $(P=0.03$, Table 2$)$. Within each light level, growing medium $\mathrm{pH}$ was lowest when ivy were grown with higher fertilizer concentrations. The fertilizer source in this experiment (20-10-20) has 7.84\% ammoniacal nitrogen ( $40 \%$ of the nitrogen is ammoniacal). This is probably the reason that $\mathrm{pH}$ was lower when ivy were fertilized at higher concentrations. $\mathrm{pH}$ values at the different light levels were within 0.2 units of one other (less than the LSD) at fertilizer concentrations from 0 to $200 \mathrm{ppm}$, but at $300 \mathrm{ppm}$, high light resulted in lower $\mathrm{pH}$ than low light. The lowest growing medium $\mathrm{pH}$ (5.01) was measured in the growing medium of ivy grown with $300 \mathrm{mg} \cdot \mathrm{L}^{-1} \mathrm{~N}$ and under $8.5 \mathrm{~mol} \cdot \mathrm{m}^{-2} \cdot \mathrm{d}^{-1}$. Averaged over all light and fertilizer treatments, 'Gold Heart' had a significantly higher substrate $\mathrm{pH}$ (5.75) than 'Gold Child' (5.68), however, the difference between the cultivars was so small that it would not be commercially important. No nutrient deficiencies or toxicity symptoms were observed in any of the ivy cultivars and under any fertilization regimes, and tissue analysis for macro- and micronutrients were within acceptable ranges (data not shown).

There was a two-way interaction between fertilizer concentration and cultivar for vine length (Fig. 4). Vine length of 'Gold Dust' ivy was not significantly affected by fertilizer concentration. 'Gold Child' ivy grown with $100 \mathrm{mg} \cdot \mathrm{L}^{-1} \mathrm{~N}$ had significantly longer vine length than those grown with more than 200 $\mathrm{mg} \cdot \mathrm{L}^{-1} \mathrm{~N}$ (Fig. 4). Vine length of 'Gold Heart' ivy was longest when plants were not fertilized. When 'Gold Heart' ivy were given any supplemental fertilizer, they had significantly shorter vines compared to non-fertilized ivy $\left(0 \mathrm{mg} \cdot \mathrm{L}^{-1} \mathrm{~N}: 58 \mathrm{~cm} ; 300 \mathrm{mg} \cdot \mathrm{L}^{-1} \mathrm{~N}: 47 \mathrm{~cm}\right)$. The starting EC of the growing medium in this experiment was $2.0 \mathrm{dS} \cdot \mathrm{m}^{-1}$. A peat-based medium with a starting EC of $3.5 \mathrm{dS} \cdot \mathrm{m}^{-1}$ had a water potential of $-0.21 \mathrm{MPA}$ (Burnett, 2004). Adding more fertilizer to a growing medium would lower the osmotic potential, and induce mild osmotic stress. This could inhibit water uptake and cell elongation (van Volkenburgh, 1999; Carpita and McCann, 2000). Fertilizer concentration did not affect shoot dry weight or leaf area of ivy in this experiment. It is possible that fertilizer had little effect, or even a slight suppressive effect on ivy growth in this experiment, because the initial EC charge of the fertilizer in the growing medium may have persisted longer in a subirrigation system, where ivy were not frequently leached, than with typical overhead irrigation.

Chlorophyll content (SPAD) was significantly lower when plants were not fertilized than when they were fertilized with more than
$100 \mathrm{mg} \cdot \mathrm{L}^{-1} \mathrm{~N}$ (Fig. 5A). According to LSD means separation, chlorophyll content was not different for ivy grown with $\geq 100 \mathrm{mg} \cdot \mathrm{L}^{-1}$. So, ivy could be fertilized with at least $100 \mathrm{mg} \cdot \mathrm{L}^{-1}$ $\mathrm{N}$ on ebb-and-flow benches. Similarly, Zheng et al. (2004) found that Gerbera jamesonii (Hook.) 'Shogun' subirrigated with $10 \%$ or $25 \%$ of a full strength commercial nutrient solution were significantly lighter green than those fertilized with $50 \%$ or $100 \%$ of the same nutrient solution. Holcomb et al. (1992) found that $50 \mathrm{mg} \cdot \mathrm{L}^{-1} \mathrm{~N}(20 \mathrm{~N}-4.4 \mathrm{P}-16.6 \mathrm{~K}$ or $20 \mathrm{~N}-8.3 \mathrm{P}-14.9 \mathrm{~K}$ ) fertilizer was best suited for subirrigating Baltic ivy on ebb-and-flow benches. However, we did not test rates below $100 \mathrm{mg} \cdot \mathrm{L}^{-1} \mathrm{~N}$. 'Gold Heart' had significantly more chlorophyll than the other two cultivars (Table 1). This is likely due to differences in the type of variegation and the pattern of its expression in each cultivar (Fig. 3A-C). 'Gold Heart' is a GGW (green-green-white) chimera, which means that the chlorophyllous green margin is more strongly expressed, compared

Table 2. Effects of $P P F$ and fertilizer on growing medium $\mathrm{pH}$ and electrical conductivity (EC) at experiment termination. The interaction between $P P F$ and fertilizer for $\mathrm{pH}$ was significant $(P=0.03)$. The interaction between fertilizer, $P P F$, and cultivar for EC of the growing medium was significant $(P=0.002)$

\begin{tabular}{lccccc}
\hline $\begin{array}{l}\text { Fertilizer } \\
\text { rate } \\
\left(\mathrm{mg} \cdot \mathrm{L}^{-1}\right)\end{array}$ & $\begin{array}{c}P P F \\
\left(\mathrm{~mol} \cdot \mathrm{m}^{-2} \cdot \mathrm{d}^{-1}\right)\end{array}$ & $\mathrm{pH}$ & 'Gold Child' & 'GC $\left(\mathrm{dS} \cdot \mathrm{m}^{-1}\right)$ & \\
\hline 0 & 3.2 & 6.74 & 0.21 & 0.20 & 0.22 \\
0 & 5.4 & 6.70 & 0.23 & 0.21 & 0.20 \\
0 & 8.5 & 6.56 & 0.26 & 0.20 & 0.20 \\
100 & 3.2 & 5.58 & 1.29 & 1.04 & 1.17 \\
100 & 5.4 & 5.57 & 1.12 & 1.08 & 1.04 \\
100 & 8.5 & 5.49 & 1.29 & 1.06 & 1.08 \\
200 & 3.2 & 5.42 & 1.97 & 1.76 & 1.77 \\
200 & 5.4 & 5.43 & 1.89 & 1.85 & 1.75 \\
200 & 8.5 & 5.40 & 1.85 & 1.91 & 1.92 \\
300 & 3.2 & 5.40 & 3.37 & 2.87 & 2.8 \\
300 & 5.4 & 5.23 & 2.78 & 3.03 & 3.02 \\
300 & 8.5 & 5.01 & 3.32 & 2.67 & 2.76 \\
LSD $_{0.05}$ & & 0.24 & & 0.22 & \\
\hline
\end{tabular}




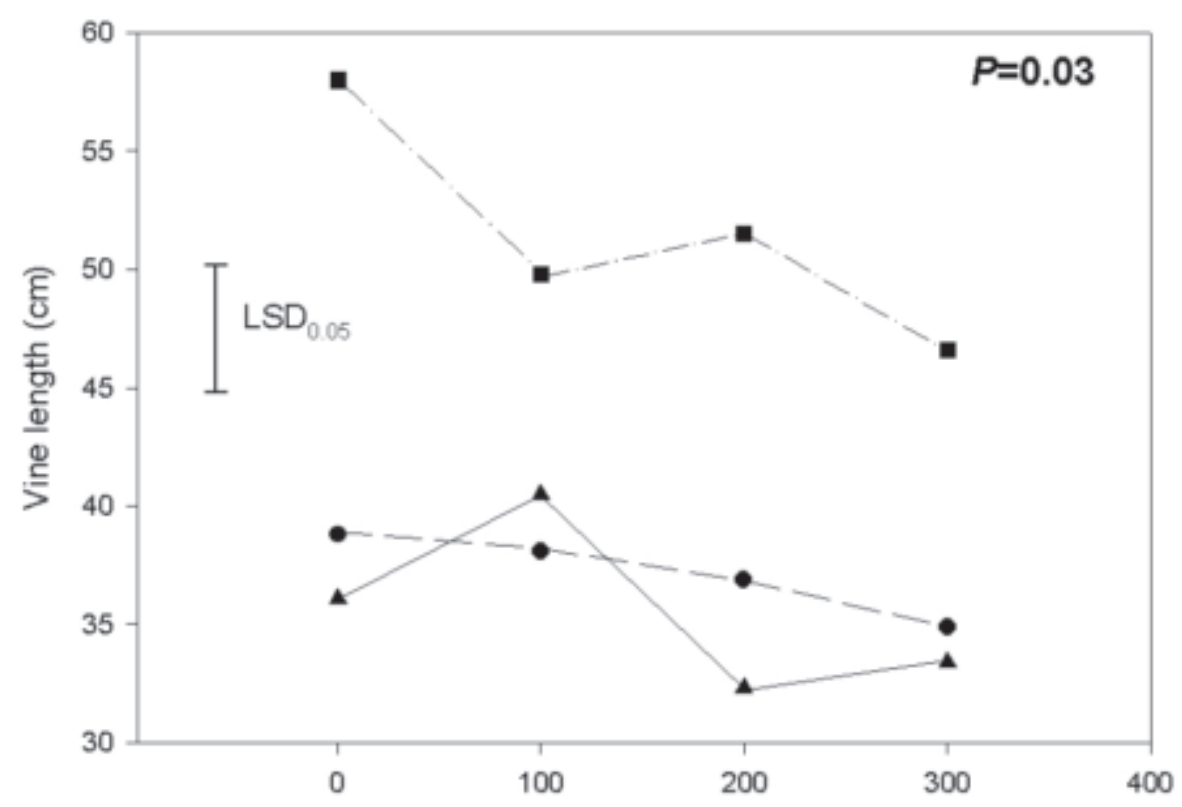

A 'Gold Child"

- 'Gold Dust'

- 'Gold Heart'

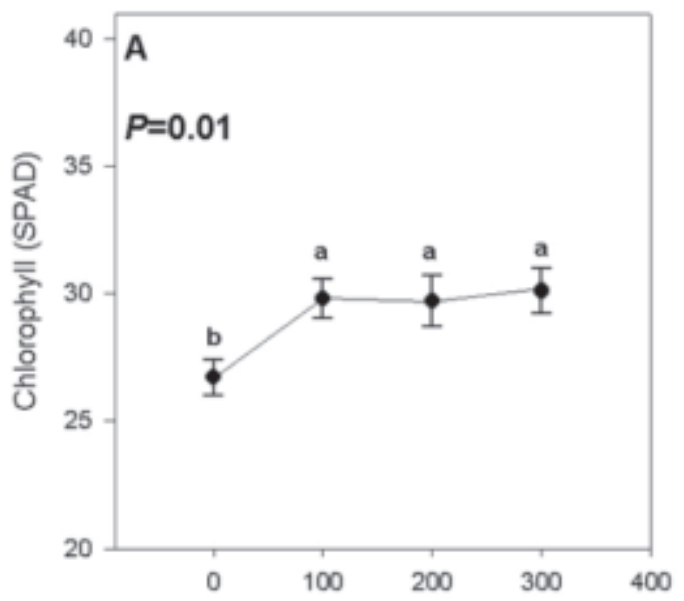

Fertilizer concentration $\left(\mathrm{mg} \mathrm{L}^{-1}\right)$

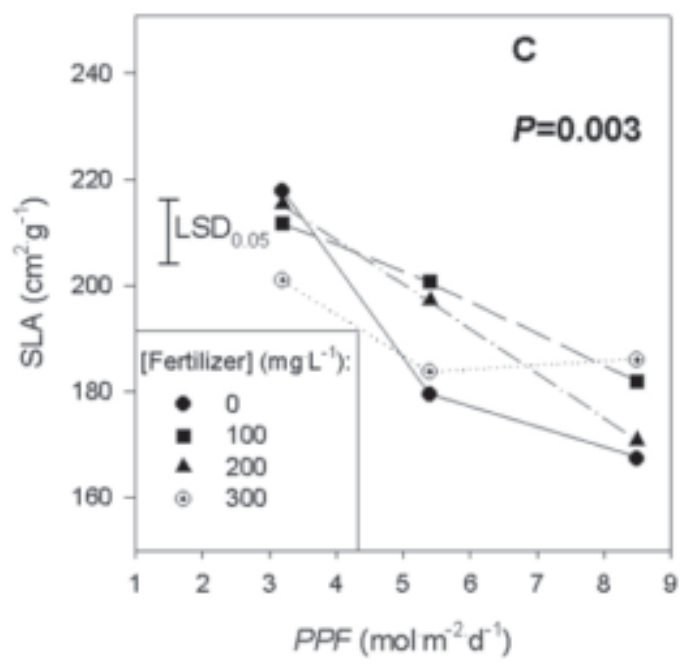

Fig. 4. Effects of fertilizer concentration on vine length of three english ivy (Hedera helix L.) cultivars: 'Gold Child', 'Gold Dust', and 'Gold Heart'. There was a two-way interaction between fertilizer concentration and cultivar; the means for each level are shown with the standard error represented by the LSD.

to 'Gold Child', a GWG (green-white-green) chimera (Tilney-Bassett, 1986). As mentioned previously, SPAD measurements were taken in the leaf margin portion of 'Gold Heart', which would result in higher chlorophyll values. 'Gold Child' has a subepidermal layer of achlorophyllous cells, which results in a lighter-green coloration of the entire leaf lamina. Although we do not know what type of chimera 'Gold Dust' is, its variegation is expressed in a highly speckled pattern of yellow and green, and many variations in between. So, it is likely that there was very little, if any, variegation in the measured portions of leaves of 'Gold Heart'. However, it would have been impossible to completely measure non-variegated leaf portions of 'Gold Dust' or 'Gold Child'.

Percent variegated leaf area was also significantly affected by fertilizer concentration (Fig. 5B). The least variegated plants were

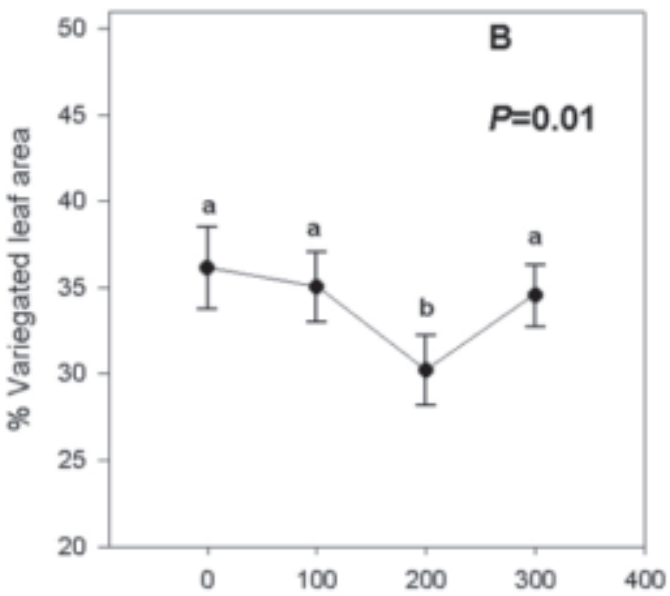

Fertilizer concentration $\left(\mathrm{mg} \mathrm{L}^{-1}\right)$
Fig. 5. Effects of fertilizer concentration on leaf chlorophyll content (A), SPAD measurement and percent variegated leaf area $(\mathbf{B})$, and the effects of fertilizer concentration and $P P F$ on specific leaf area (SLA) (C) of three english ivy (Hedera helix L.) cultivars: 'Gold Child', 'Gold Dust', and 'Gold Heart'. The means shown in A and $\mathbf{B}$ are the average for all three cultivars with standard error bars. For SLA and vine length, there was a two-way interaction; the means for each level are shown with standard error represented by the LSD. grown with $200 \mathrm{mg} \cdot \mathrm{L}^{-1} \mathrm{~N}$ There was only a $2 \%$ difference between percent variegation for the other fertilizer concentrations, which was not significantly different. Although fertilizer did significantly affect variegated leaf area, the percent change was so small (6\% difference between 0 and $200 \mathrm{mg} \cdot \mathrm{L}^{-1}$ ) that it may not be commercially important.

There was an interaction between fertilizer concentration and light level for SLA (Fig. 5C). For ivy grown with $0-200 \mathrm{mg} \cdot \mathrm{L}^{-1}$ $\mathrm{N}$ of fertilizer, SLA is the largest for plants grown under $3.2 \mathrm{~mol} \cdot \mathrm{m}^{-2} \cdot \mathrm{d}^{-1}$ and the smallest for plants grown under $8.5 \mathrm{~mol} \cdot \mathrm{m}^{-2} \cdot \mathrm{d}^{-1} P P F$. SLA was largest for ivy grown with $300 \mathrm{mg} \cdot \mathrm{L}^{-1} \mathrm{~N}$ of fertilizer at $3.2 \mathrm{~mol} \cdot \mathrm{m}^{-2} \cdot \mathrm{d}^{-1}$ $P P F$ and similar at the highest two light levels (Fig. 5C). Both 'Gold Child' and 'Gold Dust' had significantly larger SLA than 'Gold Heart' (Table 1). The interaction for SLA was the only fertilizer concentration and $P P F$ interaction observed for all the morphological variables examined in this experiment. Similarly, Nemali and van Iersel (2004) found that light level affected optimal, 
fertilizer concentrations for growth of begonia (Begonia semperflorens-cultorum Hort.); however, the effect was not large enough to be commercially important.

\section{Conclusions}

The results of this experiment indicate that for almost every variable tested, the optimal fertilizer concentration for plants was not affected by varying $P P F$ treatments. This implies that growers need not adjust the fertilizer EC based on $P P F$ when growing english ivy in subirrigation systems. Crop growth and variegation of 'Gold Child' and 'Gold Heart' was better under high than low PPF treatments. However, variegation and growth of all three cultivars was acceptable under $5.4 \mathrm{~mol} \cdot \mathrm{m}^{-2} \cdot \mathrm{d}^{-1}$ $P P F$. Based on our results, producers could grow 'Gold Child', 'Gold Dust', and 'Gold Heart' english ivy under $5.4 \mathrm{~mol} \cdot \mathrm{m}^{-2} \cdot \mathrm{d}^{-1} P P F$ and subirrigate with $100 \mathrm{mg} \cdot \mathrm{L}^{-1} \mathrm{~N}$ to produce marketable quality acclimatized plants.

\section{Literature Cited}

Al-Juboory, K.H., D.J. Williams, R.M. Skirvin, and D.G. Bullock. 1998. Influence of photoperiod, photosynthetic photon flux, and temperature on growth of Canary Island ivy. HortScience 33:237-239.

Bequette, B.L., T.M. Blessington, and J.A. Price. 1985. Influence of lighting systematics on the interior performance of two croton cultivars. HortScience 20:927-931.

Blessington, T.M. and P.C. Collins. 1993. Postproduction factors, p. 11-18. In: Foliage plantsProlonging quality. Ball Publ., Batavia, Ill.

Burnett, S.E. 2004. Effects of polyethylene glycol on the morphology of ornamental seedlings. $\mathrm{PhD}$ diss. Univ. Ga., Athens.

Carpenter, W.J. and J.P. Nautiyal. 1969. Light intensity and air movement effects on leaf temperature and growth of shade requiring greenhouse crops. J. Amer. Soc. Hort. Sci. 94:212-214.

Carpita, N. and M. McCann. 2000. The cell wall, p.
52-108. In: B.B. Buchanan, W. Gruissem, and R.L. Jones (eds.). Biochemistry and molecular biology of plants. Amer. Soc. Plant Physiol., Rockville, Md.

Conover, C.A. and R.T. Poole. 1981. Environmental factors, p. 269-283. In: J. Joiner (ed.). Foliage plant production. Prentice-Hall, Englewood Cliffs, N.J.

Cox, D.A. 2001. Growth, nutrient content, and growth medium electrical conductivity of poinsettia irrigated by subirrigation or from overhead. J. Plant Nutr. 24:523-533.

Hong, J., J.S. Lee, and B.H. Kwack. 1994. Influence of light intensity and quality, and fertilizer on growth and leaf variegation of Codiaeum variegatum 'Yellow Jade' for indoor landscaping. J. Kor. Soc. Hort. Sci. 35:610-616.

Holcomb, E.J., S. Gamez, D. Beattie, and G.C. Elliot. 1992. Efficiency of fertigation programs for baltic ivy and asiatic lily. HortTechnology 2:43-46.

HyeRan, K., L. JongSuk, S. ChungNam, and N. YooKyung. 1998. Quantifying the extent of leaf-variegation for Tradescantia using computer graphic analysis. Kor. J. Hort. Sci. Technol. 16:364-365.

James, E.C. and M.W. van Iersel. 2001. Fertilizer concentration affects growth and flowering of subirrigated petunias and begonias. HortScience 36:40-44.

Kent, M.W. and D.W. Reed. 1996. Nitrogen nutrition of new guinea impatiens 'Barbados' and Spathiphyllum 'Petite' in a subirrigation system. J. Amer. Soc. Hort. Sci. 121:816-819.

McConnell, D.B., R.W. Henley, and C.B. Kelly. 1989. Commercial foliage plants: Twenty years of change. Proc. Florida. State Hort. Soc. 102:297-303.

Nam, Y.K. and B.H. Kwack. 1992. Effect of different levels of light, gibberellin, nitrogen, potassium and phosphate applications on leaf-yellowing of Lonicera japonica var. aureo-reticulata. J. Kor. Soc. Hort. Sci. 33:54-61.

Nemali, K.S. and M.W. van Iersel. 2004. Light intensity and fertilizer concentration: I. Estimating optimal fertilizer concentrations from water-use efficiency of wax begonia. HortScience 39:1287-1292.
Pennisi, B.V., R.D. Oetting, F.E. Stegelin, P.A. Thomas, and J.L. Woodward. 2001. Commercial production of english ivy (Hedera helix L.). Univ. Ga. Coop. Ext. Serv. Expt. Sta. Bul. 1206.

Shen, G.W. and J.G. Seeley. 1983. The effect of shading and nutrient supply on variegation and nutrient content of variegated cultivars of Peperomia obtusifolia. J. Amer. Soc. Hort. Sci. 108:429-433.

Stamps, R.H. 1995. Effects of shade level and fertilizer rate on yield and vase life of Aspidistra elatior 'Variegata' leaves. J. Environ. Hort. 13:137-139.

Tilney-Bassett, R.A.E.. 1986. Plant chimeras. Edward Arnolds Publ., Cambridge Univ. Press, Cambridge.

Uva, W.L., T.C. Weiler, and R.A. Milligan. 1998. A survey on the planning and adoption of zero runoff subirrigation systems in greenhouse operations. HortScience 34:660-663.

U.S. Dept. of Agriculture. 2001. Floriculture crops 2001 summary. U.S. Dept. Agr., Wash., D.C.

van Iersel, M.W. 1996. Improving water and fertilizer efficiency in greenhouses. Ga. Floricult. 6(3):22-23.

van Volkenburgh, E. 1999. Leaf expansion-An integrating plant behavior. Plant Cell Environ. 22:1463-1473.

Vladimirova, S.V., D.B. McConnell, M.E. Kane, and R.W. Henley. 1997. Morphological plasticity of Dracaena sanderana 'Ribbon' in response to four light intensities. HortScience 32:1049-1052.

Yeager, T., C. Gilliam, T. Bilderback, D. Fare, A. Niemiera, and K. Tilt. 1997. Best management practices: Guide for producing container-grown plants. S. Nurserymen's Assn., Marietta, Ga.

Yeh, D.M. and P.Y. Hsu. 2004. Differential growth and photosynthetic response of selected cultivars of english ivy to irradiance. J. Hort. Sci. Biotechnol. 79:633-637.

YuKyeong, N., K. HyeRan, and K. BeyoungHwa. 1997. Different extents of leaf-variegation in Epipremnum aureum as influenced by different light levels. J. Kor. Soc. Hort. Sci. 38:537-540.

Zheng, Y., T. Graham, S. Richard, and M. Dixon. 2004. Potted gerbera production in a subirrigation system using low-concentration nutrient solutions. HortScience 39:1283-1286. 